\title{
Cardiovascular Disease Among International Travellers
}

\author{
Daniel Oppong Mensah ${ }^{1 *(\mathbb{Q}}$, Padam Simkhada ${ }^{1,2}{ }^{(1)}$ \\ ${ }^{1}$ Public Health Institute, Liverpool John Moores University, Liverpool, UK \\ ${ }^{2}$ School of Human and Health Sciences, University of Huddersfield, Huddersfield, UK
}

Corresponding Author: Daniel Oppong Mensah, RD, LD, MSc, Public Health Institute, Liverpool John Moores University, Liverpool, UK. Tel.: +44-233-2546448, Email: mensahoppong@gmail.com

Received November 11, 2020; Accepted April 6, 2021; Online Published June 26, 2021

\begin{abstract}
Introduction: Cardiovascular disease (CVD) is the leading cause of death among international travellers. This study aims to estimate the proportion of travellers diagnosed with CVD during international travel.

Methods: A narrative synthesis of peer-reviewed literature was conducted on CVD among international travellers. Healthcare databases and sources of grey literature were searched using pre-defined criteria between February and June 2019. Two reviewers screened all the identified studies against protocol and extracted data using a piloted form.

Results: Eight studies were eligible for final analysis. Four studies evaluated data from GeoSentinel Clinic databases. The number of study participants varied across studies from a minimum of 24 to a maximum of 63076 . Between $0.1 \%$ and $14 \%$ of international travellers were reported or diagnosed with CVD while travelling abroad. CVD was common in male travellers as compared with female travellers. There was a lack of information on pre-existing morbidity, smoking status, obesity in all included studies.

Conclusion: This review provides a first-time estimate of the proportion of international travellers with CVD while travelling overseas. Hence, preventive measures to minimize CVD risk such as sufficient exercises during long-distance flights, progressive acclimatization to altitude, wearing a face mask in polluted areas, maintaining a healthy lifestyle, and nutrition during travelling should be considered. CVD should be an important part of pre-travel health advice.

Keywords: Risk Factors, Pre-travel Health Consultation, Overseas
\end{abstract}

Citation: Mensah DO, Simkhada P. Cardiovascular disease among international travellers. Int J Travel Med Glob Health. 2021;9(3):107-112 doi:10.34172/ijtmgh.2021.18.

\section{Introduction}

Globally, cardiovascular disease (CVD) and its risk factors, such as tobacco use, high blood pressure, obesity, and lack of physical inactivity are the leading causes of morbidity and mortality. ${ }^{1,2}$ The international commitment to address this issue is very clear, thus the Sustainable Development Goals ${ }^{3}$ and the WHO $25 \times 25$ Global Action Plan ${ }^{4}$ have set targets to reduce premature mortality from CVD. Yet, CVD remains the most common cause of mortality in all human populations. ${ }^{5,6}$

International travel continues to increase significantly, with over 1.5 billion travellers worldwide in 2019 and this figure is projected to reach 1.8 billion by $2030 .^{7,8}$ International travel may pose risks to cardiovascular health, depending on both the health needs of travellers and the type of travel undertaken. ${ }^{9,10}$ Travellers may encounter sudden and significant changes in altitude, humidity, temperature, pollution, which may result in cardiac events. ${ }^{9}$ All travelling individuals are often advised to seek advice on the potential hazard in their chosen destinations and understand how best to protect their health. ${ }^{9,11}$ However pre-travel health consultations often emphasize infectious diseases; diarrhoea, malaria, hepatitis $\mathrm{A}$ and $\mathrm{B}$, typhoid fever, tetanus/diphtheria, influenza, pneumococcus, polio, meningitis, measles, mumps, rubella, varicella, and rabies. ${ }^{11-13}$ Meanwhile, evidence suggests that infectious disease accounts for only one- percent of all traveller deaths despite being a prominent focus for travel clinics and government agencies working to reduce risk abroad. ${ }^{14}$

Reports among Australian, Canadian, and Finnish citizens travelling abroad indicate that CVD accounts for the greatest proportion of all deaths during travel. ${ }^{15-17}$ One study on US travellers found that $49 \%$ of all deaths were due to CVD, much more than deaths due to accidents and infections. ${ }^{14}$

Given that CVD is the leading cause of death among international travellers ${ }^{7}$; therefore, there is a need for accurate data on the proportion of international travellers who are reported or diagnosed with CVDs while travelling overseas. ${ }^{18}$ However, to the best of our knowledge, no study has been conducted. The present study aimed to fill the knowledge gap

Copyright $($ C 2021 The Author(s). This is an open-access article distributed under the terms of the Creative Commons Attribution License (http:// creativecommons.org/licenses/by/4.0), which permits unrestricted use, distribution, and reproduction in any medium, provided the original work is properly cited. 
and contribute to CVD prevention programs. Estimating the proportion of international travellers who acquire a travelrelated disease (CVD) is useful in observing trends over time. ${ }^{19}$ Additionally, it is essential for health professionals who offer health advice to travellers to enable them to pass on optimal pre-travel advice to their patients.

\section{Methods}

A combination of the following keywords was used as search terms "international travel ${ }^{*}$ " OR "overseas travel ${ }^{*}$ " OR "foreign travel*” OR "international visit*" OR "inter ${ }^{\star}$ continental travel*" OR "global travel ${ }^{\star}$ " AND "Cardiovascular diseases" OR ((cardiovascular OR heart) N1 disease) OR angina OR stroke OR blood pressure OR hypertension OR myocardial infarction OR ischemic heart disease OR heart failure OR cardiac event* ${ }^{\star}$ in order to broaden the search. Only observational studies (prospective and retrospective, casecontrol, cross-sectional studies, etc) reporting on the incidence of CVD among international travellers were included in this study. This is because observational studies rely on natural and "ecological" events of exposure and disease, where the researchers simply observe certain characteristics of the sample population as they occur "naturally" and record the relevant. ${ }^{20}$ The underpinning research question was What proportion of international traveller's are reported or diagnosed with the CVD while travelling abroad? The term international travel or traveller(s) was defined according to the World Tourism Organisation (UNWTO) ${ }^{21}$ definition. Thus, the purpose of travelling should be classified under one of the following headings: leisure (including recreation, holiday, health, study, religion, and sport), excursion, business, family visits, and conferences. Research papers on migrants, refugees and internal displacement persons, local travellers (people travelling within the same country of origin) were excluded from this review. A comprehensive search was conducted in the following databases; Web of Science, MEDLINE, PsycINFO, CINAHL. Searches were performed in the later part of 2019 using Liverpool John Moores University's electronic library and restricted to peerreviewed studies in the publication timeframe from January 2000 to December 2019. Studies included were limited to only English Language and studies from all geographical settings were also included. In addition, reference lists from relevant research papers and documents were manually screened. Searches were conducted by breaking down the review question into Population and Outcomes elements as detailed in Table 1. Boolean terms 'AND', 'OR' were used to combine different elements of the search. Initial keywords were subject to the Boolean term, OR. It was then combined using the Boolean operator 'AND'. Database-specific terms and filtering options were utilized where appropriate. To produce a complete search 'SubjectMajor and MeSH' terms were used where applicable. The search strategies were peer-reviewed by a librarian to ensure methodological quality. Titles and abstracts of articles returned from the databases were screened based on the eligibility criteria. Full texts were examined in detail and screened for eligibility. References of all relevant
Table 1. Search terms

\begin{tabular}{ll}
\hline \multicolumn{1}{c}{ Population } & \multicolumn{1}{c}{ Outcomes } \\
\hline & MesH" Cardiovascular diseases" \\
"international travel*" OR & OR ((cardiovascular OR \\
"overseas travel*"OR "foreign & heart) N1 disease) OR angina \\
travel*" OR "international visit*" & OR stroke OR blood pressure \\
OR "inter*continental travel*" & OR hypertension OR myocardial \\
OR "global travel*" & infarction OR ischemic heart \\
& disease OR heart failure OR \\
& cardiac event* \\
\hline
\end{tabular}

articles were hand-searched to identify any relevant studies. A search of grey literature was also conducted. A flow chart (Figure 1) was used to report the number of studies remaining at each stage of the study selection. All included studies from PubMed, CINAHL Plus, and Web of science were transferred to the Endnote X6 software package (Thomson Reuters, San Francisco, CA, USA) ${ }^{22}$ where duplicates were removed. Two independent reviewers were involved in the screening and selection of articles. Data extraction was performed using Microsoft Excel. Details extracted were categorised into author, year, study design, sample characteristics, the purpose of travelling, and outcome measures.

\section{Summary Measures and Synthesis of Results}

In this study, statistical pooling was not feasible due to the high level of heterogeneity and lack of available data to calculate standardized effect estimates (e.g., odds ratio, risk ratio, and standardized mean difference). Furthermore, information on statistical significance was missing from many included studies. ${ }^{23}$ Therefore, a qualitative approach was adopted to narratively synthesize the results. Hence, a qualitative approach was adopted to narratively synthesize the results.

\section{Results \\ Study Selection and Study Characteristics}

After inputting the comprehensive search terms (Table 1) into the three databases, the records of 4997 studies were identified from the searches and other sources. After the removal of duplicates and application of the inclusion/ exclusion criteria, 58 articles were identified for a full-text review. A further 50 were removed for being irrelevant to the topic. We identified eight studies for the final analysis. All the studies were observational. Four studies evaluated the data from the GeoSentinel clinics' database ${ }^{24-27}$ and three studies analysed the data from population-based registries. ${ }^{28-30}$ One study had enrolled study participants directly. ${ }^{31}$

\section{Purpose of Travelling}

The main purposes of travelling among all study participants were as follows: tourism/holidays (48\%), business (44\%), volunteering (4\%), visiting friends and relatives (2\%), professional (1\%) and others (1\%). 'Others travellers' included those on medical tourism and military purposes.

\section{Summary of Evidence}

The percentage proportion of study participants who were reported or diagnosed with CVD during international travel 


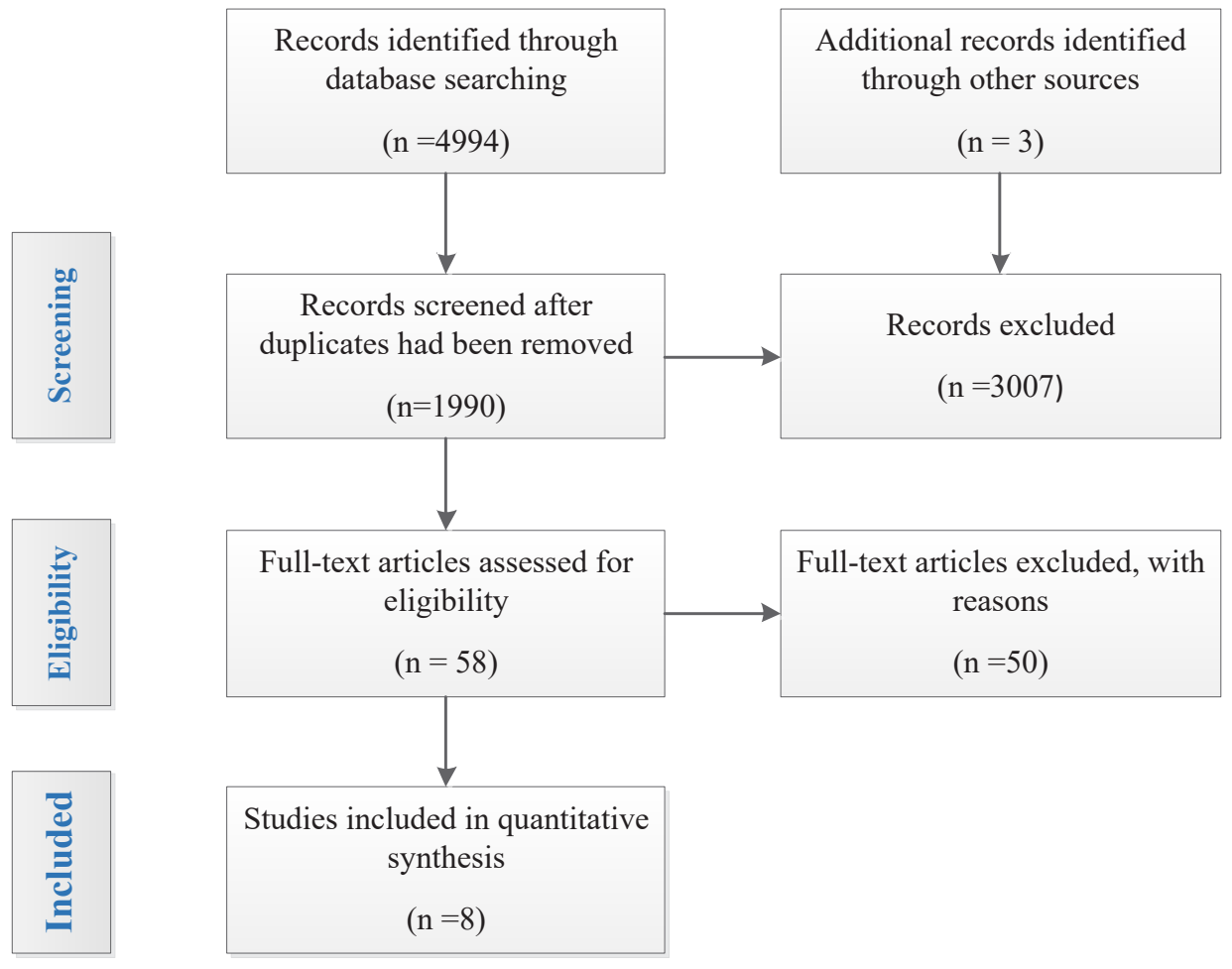

Figure 1. Study Selection.

varied across studies from a maximum of $14 \%^{31}$ to a minimum of $0.1 \%{ }^{24} \mathrm{CVD}$ was reported or diagnosed more commonly in male travellers than that of female travellers. ${ }^{27,29,30}$ Sanftenberg and colleagues reported that women were less likely to be reported or diagnosed with CVD during international travel as compared to men (OR, 0.56; 95\% CI, 0.47-0.66). ${ }^{27}$

Proportionate morbidity due to CVD was higher in old travellers compared to that of young travellers. ${ }^{26,30}$ Gautret and colleagues revealed a linear positive association between age, heart disease, and death among international travellers. These trends were very significant $(P<0.001) .{ }^{26}$ Four studies provided data on how travel destination impacts $\mathrm{CVD}^{28-31}$; Sanftenberg and colleagues reported that $7.7 \%$ of German business travellers to China were reported or diagnosed with CVD while Shaw and colleagues ${ }^{31}$ noted that $14 \%$ of travellers on a premium tour to Indochina were reported of CVD. Additionally, Thompson and colleagues ${ }^{30}$ reported that $6.3 \%$ of tourists who visited Jamaica were reported or diagnosed with CVD while Lerdal and colleagues found a high incidence of CVD (5.3\%) among Norwegian travelling to Southern and Eastern Europe as compared to other regions. ${ }^{28}$ However, all these studies lacked statistical power (statistically insignificant). Four studies provided data on travel duration..$^{25-27,31}$ However, there was no evidence of a clear pattern as to how the travel duration impacted CVD. Five studies provided data on pre-travel health consultation. However, the impact of pre-travel health consultation on CVD was not assessed. The most important analytic characteristics are displayed in Table 2.

\section{Discussion}

To the best of our knowledge, this is the first narrative review in this field that estimates the proportion of travellers dignosed with CVD while traveling abroad. A major strength of this review is the analysis of studies published from 2000 to 2019. This narrative review was built on a strong foundation; there were clear search strategies, fully documented inclusion and exclusion criteria, decision-making by more than one researcher, and clearly documented data extraction. We have complete confidence that we have not missed any major sources of evidence and that any conclusion drawn is firmly rooted in the best evidence available.

Generally, gender is one of the key socio-demographic variables that can influence travel behaviour. ${ }^{32}$ Research implicates gender as a risk factor for travel-related illness. ${ }^{27}$ In this review, there was a high incidence of CVD among men than women. ${ }^{27,29,30}$ This may be due to the complexity of activities more often experienced by women rather than men during travelling. Thus, women are more likely to commute short distances, have more non-work-related trips, travel at off-peak hours, and choose more flexible modes compared to men. ${ }^{33,34}$ Hence, gender should be an important part of pretravel health advice. Morbidity associated with CVD during travelling was higher in older travellers. It was estimated that 15 to $30 \%$ of the total number of international travellers are people aged 60 years and over. ${ }^{26}$ There is also a greater tendency of a cardiac event in this age group. ${ }^{26,30}$ Hence healthcare professionals should consider age as an important factor when they are advising people travelling internationally.

Older travellers should take precautions to prevent potential exacerbations of cardiovascular health during international travel. It is recommended that older travellers should use anti-thrombosis compression stockings, maintain sufficient hydration and exercise during long-distance travel. This help 
Table 2. Summary of Extracted Data

\begin{tabular}{|c|c|c|c|c|}
\hline Author/ Year & $\begin{array}{l}\text { Summary of Methods/ Time-Frame/ Study } \\
\text { Design }\end{array}$ & Sample Characteristics & $\begin{array}{l}\text { Purpose of } \\
\text { Travel }\end{array}$ & Relevant Findings/Outcome \\
\hline $\begin{array}{l}\text { Chen et al, } \\
2018^{24}\end{array}$ & $\begin{array}{l}\text { Descriptive analysis was performed on ill } \\
\text { business travellers from 1997-2014. Traveller } \\
\text { were evaluated after an international travel at } \\
\text { GeoSentinel clinic. } \\
\text { Study design: Cross-sectional study }\end{array}$ & $\begin{array}{l}\mathrm{N}-12203 \\
\mathrm{M}-67 \% \mathrm{~F}-33 \% \\
\text { Age range } \\
20-64,65 \text { years }\end{array}$ & Business-(100\%) & $\begin{array}{l}26(0.1 \%) \text { were diagnose of CVD after an } \\
\text { international travel at GeoSentinel clinic. } \\
\text { Travel duration - Not specified } \\
\text { P-value was not documented. }\end{array}$ \\
\hline $\begin{array}{l}\text { Freedman et al, } \\
2006^{25}\end{array}$ & $\begin{array}{l}\text { Thirty GeoSentinel sites data for ill returned } \\
\text { travellers from developing world were } \\
\text { analysed from } 1996 \text { to } 2004 \text {. } \\
\text { Study design: Cross-sectional study }\end{array}$ & $\begin{array}{l}\mathrm{N}-17,353 \\
\mathrm{M}-52 \% \mathrm{~F}-48 \% \\
\text { Age range } \\
26-45 \text { years }\end{array}$ & $\begin{array}{l}\text { Tourism-59\% } \\
\text { Business-14\% } \\
\text { *Professional- } 4 \% \\
\text { Volunteer-8\% } \\
\text { VFR-8\% } \\
\text { Others-7 } \\
\end{array}$ & $\begin{array}{l}139(0.8 \%) \text { international travellers were } \\
\text { diagnosed of CVD after travelling to the } \\
\text { developing world. } \\
\text { P-value was not documented. } \\
\text { Travel duration- } 23 \text { days }\end{array}$ \\
\hline $\begin{array}{l}\text { Gautret et al, } \\
2012^{26}\end{array}$ & $\begin{array}{l}\text { Medical data were collected on ill } \\
\text { international travellers presenting to } \\
\text { GeoSentinel sites from } 1997 \text { to } 2009 \text {. } \\
\text { Patients aged } 60 \text { years and over were } \\
\text { compared to patients aged } 18-45 \text { years } \\
\text { Study design: Cross-sectional study }\end{array}$ & $\begin{array}{l}\mathrm{N}-63076 \\
\mathrm{~F}-50.3 \% \mathrm{M}-49.7 \% \\
\text { Age range } \\
18-45 \text { years, } \\
\geq 60 \text { years }\end{array}$ & $\begin{array}{l}\text { Tourism- } 60 \% \\
\text { Business-20.05\% } \\
\text { *Professional- } 1.2 \% \\
\text { Volunteer- } 10.9 \% \\
\text { VFR-7.5\% } \\
\text { Others- } 0.35 \%\end{array}$ & $\begin{array}{l}\text { The number of person diagnosed with CVD } \\
\text { were } 519(0.8 \%) \text { at various GeoSentinel } \\
\text { sites. However, it was statistically significant } \\
\text { compared to other medical diagnosis. } \\
\text { Travel duration- } 25 \text { days }\end{array}$ \\
\hline $\begin{array}{l}\text { Sanftenberg et al, } \\
2010^{27}\end{array}$ & $\begin{array}{l}\text { Data from GeoSentinel network's sites from } \\
1997 \text { to } 2007 \text { according to demographic } \\
\text { characteristics and travel related morbidity } \\
\text { were analysed. } \\
\text { Study design: Cross-sectional study }\end{array}$ & $\begin{array}{l}\mathrm{N}-58,908 \\
\mathrm{~F}-50.3 \% \mathrm{M}-49.7 \% \\
\text { Age range- } \\
\leq 30, \leq 30 \text { years }\end{array}$ & $\begin{array}{l}\text { Business-24.5\% } \\
\text { Tourism- } 61.7 \% \\
\text { Professional- } 1.6 \% \\
\text { Voluntary }-10.6 \% \\
\text { Others- } 1.6 \%\end{array}$ & $\begin{array}{l}622(2.1 \%) \text { were diagnose of CVD. Of } \\
\text { which females were } 211(0.7 \%) \text { and males } \\
411(1.4 \%) \text {. There was a significant difference } \\
\text { between both gender }(p<0.001) \text {. } \\
\text { Travel duration- }>30 \text { days }\end{array}$ \\
\hline $\begin{array}{l}\text { Lerdal et al, } \\
2007^{28}\end{array}$ & $\begin{array}{l}\text { Data from Norway's largest insurance } \\
\text { company was analysed for prevalence of } \\
\text { illness and injury according to age, gender, } \\
\text { type of illness or injury, travel destination, } \\
\text { type of travel, and the impact on return travel } \\
\text { in } 2013 . \\
\text { Study design: Cross-sectional study }\end{array}$ & $\begin{array}{l}\mathrm{N}-1786 \\
\mathrm{M}-54.5 \% \mathrm{~F}-45.5 \% \\
\text { Age range } \\
4523.4 \text { years }\end{array}$ & $\begin{array}{l}\text { Business-93.5\% } \\
\text { Tourism-6.5\% }\end{array}$ & $\begin{array}{l}125(6.2 \%) \text { reported of CVD } \\
\text { However, p-value was not specified. } \\
\text { Travel duration- Not specified. }\end{array}$ \\
\hline $\begin{array}{l}\text { Sanftenberg et al, } \\
2019^{29}\end{array}$ & $\begin{array}{l}2011 \text { to 2013, calls for service of German } \\
\text { business travellers to China were collected by } \\
\text { a medical assistance provider and evaluated. } \\
\text { Study design: Cross-sectional study }\end{array}$ & $\begin{array}{l}\mathrm{N}-432 \\
\mathrm{M}-73.9 \% \mathrm{~F}-26.1 \% \\
\text { Age range-Not specify }\end{array}$ & Business $(100 \%)$ & $\begin{array}{l}37(7.7 \%) \text { reported of CVD. Of which } \\
31(83.8 \%) \text { were males and } 6(16.2 \%) \\
\text { were females. However, p-value was not } \\
\text { documented. } \\
\text { Travel duration- Not specified }\end{array}$ \\
\hline $\begin{array}{l}\text { Thompson et al, } \\
2003^{30}\end{array}$ & $\begin{array}{l}\text { Records of health problems occurring in } \\
\text { tourists who visited Jamaica from } 1998 \text { to } \\
2002 \text { were reviewed for the type of illness and } \\
\text { how the problem was handled. } \\
\text { Study design: Cross-sectional study }\end{array}$ & $\begin{array}{l}\mathrm{N}-743 \\
\mathrm{M}-49.8 \% \mathrm{~F}-50.2 \% \\
\text { Age range } \\
\geq 5, \geq 60+\text { years }\end{array}$ & Tourism-100\% & $\begin{array}{l}47(6.3 \%) \text { reported CVD as an occurrence } \\
\text { of Illness while visiting Jamaica. } 33(4.44 \%) \\
\text { males and } 14(1.88) \text { females reported with } \\
\text { CVD. } \\
\text { P-value- Not specified } \\
\text { Travel duration- Not specified }\end{array}$ \\
\hline $\begin{array}{l}\text { Shaw et al, } \\
2009^{31}\end{array}$ & $\begin{array}{l}\text { The tour physician diagnosed and recorded } \\
\text { all illnesses and injuries among travellers on a } \\
\text { premium tour to Indochina in } 2004 \text {. } \\
\text { Study design: Cross-sectional study }\end{array}$ & $\begin{array}{l}\mathrm{N}-24 \\
\mathrm{M}-34.3 \% \mathrm{~F}-65.7 \% \\
\text { Age range- } 62 \pm 13 \text { years }\end{array}$ & Tourism-100\% & $\begin{array}{l}\text { Primary illnesses diagnosed related to CVD } \\
\text { was } 14 \% \text { among travellers. } \\
\text { P-value not specified. } \\
\text { Travel duration- } 18 \text { days }\end{array}$ \\
\hline
\end{tabular}

F, females; M, males; N, sample size; VFR, Visiting family and relatives

Note: Professional stands for Research/education. Others stands for medical tourism, military. Risk factors assessed were age, gender, travel destinations and travel medium used.

to protect their cardiovascular health and minimize the risk of cardiac events when travelling., ${ }^{9,10}$

\section{Limitations}

There was no information on pre-existing morbidity, smoking state, obesity that could all independently impact the prognosis. The study population is probably not representative of the general travellers hence there could be selection bias. In addition, the lack of randomization in all included studies may bias the results. Since randomisation provides a rigorous tool to examine cause-effect relationships between exposure and outcome. Studies included in this review vary, particularly regarding setting, data collection, outcomes measures, and types of analysis, thus making it difficult to make direct comparisons across studies.

\section{Conclusion}

There was an incidence of CVD related to international travel in all included studies that collectively suggesting the exposure to varying levels of cardiovascular risk factors during international travel. There was a substantial knowledge gap on how traveller's lifestyle and behaviour-risk have impacts on CVD. The effect of frequent international travels on CVD still needs to be studied. Nevertheless, this review has set the stage in providing data on the number of people affected by the CVD during international travel.

\section{Recommendation}

Comprehensive data collection would be an important step in providing more useful information that is not currently available with respect to pre-existing health conditions, pre- 


\section{Review Highlights}

\section{What Is Already Known?}

CVD is the leading cause of death among international travellers. However, there are no data on the proportion of international travellers who are reported or diagnosed with CVD while travelling overseas in travel medicine literature.

\section{What Does This Study Add?}

In this narrative review, we provide an accurate estimate of the proportion of international travellers who are reported or diagnosed with CVD while travelling abroad. This review underscores the need for international travellers to seek advice on the potential hazards in their chosen destinations and understand how best to protect their cardiovascular health and minimize the risk of cardiovascular health events while travelling.

existing knowledge about the destination, the exact nature of the travel (e.g. business, visiting friends and relatives, education, holiday), length of stay in the host country, the type of CVD, and major risk factors associated with CVD during international travel.

\section{Health Action Needed}

CVD is the greatest contributor to morbidity and mortality worldwide hence healthcare professionals need to maximise their impact on the prevention of this avoidable illness, health protection, and promotion of well-being for all. Healthcare professionals involved in travel medicine should endeavour to make every contact count, encourage behaviour change to reduce the risk with a focus on a poor diet, smoking, and excess alcohol during international travelling.

International travel exposes many people to a range of health risks. Many of these risks can be minimized by precautions taken in advance during, and after travel. Hence healthcare professionals need to be skilled and competent to offer timely advice and information relating to international travel.

\section{Authors' Contributions}

PS was responsible for study conception. DOM was responsible for literature search, writing, and revision of the first draft of the manuscript. PS supervised and edited the draft manuscript.

\section{Conflict of Interest Disclosures}

The authors declare that they have no conflicts of interest.

\section{Ethical Approval}

Not applicable.

\section{Funding/Support}

None.

\section{References}

1. Yusuf S, Hawken S, Ounpuu S, et al. Effect of potentially modifiable risk factors associated with myocardial infarction in 52 countries (the INTERHEART study): case-control study. Lancet. 2004;364(9438):937-952. doi:10.1016/s01406736(04)17018-9 .

2. Dugani SB, Hydoub YM, Ayala AP, et al. Risk Factors for Premature Myocardial Infarction: A Systematic Review and Meta-analysis of 77 Studies. Mayo Clin Proc Innov Qual Outcomes. 2021;5(4):783-794. doi:10.1016/j. mayocpiqo.2021.03.009.

3. Griggs D, Stafford-Smith M, Gaffney O, et al. Policy: sustainable development goals for people and planet. Nature. 2013;495(7441):305-307. doi:10.1038/495305a.

4. Yusuf S, Hawken S, Ounpuu S, et al. Effect of potentially modifiable risk factors associated with myocardial infarction in 52 countries (the INTERHEART study): case-control study. Lancet. 2004;364(9438):937-952. doi:10.1016/s01406736(04)17018-9.

5. Bhatnagar A. Environmental determinants of cardiovascular disease. Circ Res. 2017;121(2):162-180. doi:10.1161/ circresaha.117.306458.

6. World Health Organization. Cardiovascular diseases (CVDs): 2017. Available at: https://www.who.int/news-room/factsheets/detail/cardiovascular-diseases-(cvds). Accessed July 10. 2019.

7. World Health Organization. UNWTO Tourism Highlights 2019 Edition. Available at: https://webunwto.s3.euwest-1.amazonaws.com/s3fs-public/2020-01/UNWTO_ Barom20_01_January_excerpt.pdf. Accessed January 92020.

8. World Health Organization. UNWTO Tourism Highlights 2018 Edition. Available at: https://www.e-unwto.org/doi/ pdf/10.18111/9789284419876. Accessed July 9, 2019.

9. World Health Organization. International travel and health Situation 2012; Available at: http://apps.who.int/bookorders/ MDIbookPDF/Book/18000079.pdf. Accessed July 10, 2019.

10. Stadtländer CTK. CDC health information for international travel 2016. Am J Trop Med Hyg. 2016;95(5):1219-1220. doi:10.4269/ajtmh.16-0627.

11. Centers for Disease Control and Prevention (CDC). CDC Health Information for International Travel 2014: The Yellow Book. Oxford University Press; 2013.

12. Leutscher PD, Bagley SW. Health-related challenges in United States Peace Corps Volunteers serving for two years in Madagascar. J Travel Med. 2003;10(5):263-267. doi:10.2310/7060.2003.2690.

13. Brunette GW. CDC Yellow Book 2018: Health Information for International Travel. Oxford University Press; 2017.

14. Hargarten SW, Baker TD, Guptill K. Overseas fatalities of United States citizen travelers: an analysis of deaths related to international travel. Ann Emerg Med. 1991;20(6):622-626. doi:10.1016/s0196-0644(05)82379-0.

15. Leggat PA, Wilks J. Overseas visitor deaths in Australia, 2001 to 2003. J Travel Med. 2009;16(4):243-247. doi:10.1111/j.17088305.2009.00302.x.

16. MacPherson DW, Gushulak BD, Sandhu J. Death and international travel--the Canadian experience: 1996 to 2004. J Travel Med. 2007;14(2):77-84. doi:10.1111/j.17088305.2007.00107.x.

17. Lunetta P. Injury deaths among Finnish residents travelling abroad. Int J Inj Contr Saf Promot. 2010;17(3):161-168. doi:10.1080/17457300903453112.

18. Carballo M, Mboup M. International migration and health. [Online] Iom.int. 2019; Available at: https://www.iom.int/jahia/ webdav/site/myjahiasite/shared/shared/mainsite/policy_and_ 
research/gcim/tp/TP13.pdf. Accessed August 12, 2019.

19. van Wee B, Ettema D. Travel behaviour and health: a conceptual model and research agenda. J Transp Health. 2016;3(3):240248. doi:10.1016/j.jth.2016.07.003.

20. The Joanna Briggs Institute Reviewers' Manual. Observational Study Designs - JBI Reviewer's Manual - JBI GLOBAL WIKI., 2019: Available at: https://wiki.joannabriggs.org/display/MAN UAL/7.2.1+Observational+Study+Designs. Accessed August 12,2019

21. World Tourism Organization. Collection of Tourism Expenditure Statistics. Technical Manual No.2 (English version). World Tourism Organization; 1995. Available at; https://www.e-unwto.org/doi/book/10.18111/9789284401062. Accessed July 9, 2019.

22. Thomson Reuters, San Francisco, CA, USA. EndNote. 2020, Available at; https://endnote.com/downloads/. Accessed January 12, 2019.

23. Ottawa Hospital Research Institute. The Newcastle-Ottawa Scale (NOS) for Assessing Non-Randomised Studies in Metaanalysis, 2014. Available at; www.ohri.ca/programs/clinical_ epidemiology/oxford.asp. Accessed August 12, 2019.

24. Chen LH, Leder K, Barbre KA, et al. Business travel-associated illness: a GeoSentinel analysis. J Travel Med. 2018;25(1):tax097. doi:10.1093/jtm/tax097.

25. Freedman DO, Weld LH, Kozarsky PE, et al. Spectrum of disease and relation to place of exposure among ill returned travelers. $\mathrm{N}$ Engl J Med. 2006;354(2):119-130. doi:10.1056/NEJMoa051331.

26. Gautret P, Gaudart J, Leder K, et al. Travel-associated illness in older adults (>60 y). J Travel Med. 2012;19(3):169-177. doi:10.1111/j.1708-8305.2012.00613.x.

27. Schlagenhauf P, Chen LH, Wilson ME, et al. Sex and gender differences in travel-associated disease. Clin Infect Dis. 2010;50(6):826-832. doi:10.1086/650575.

28. Lerdal A, Harding T, Kjølstad S. Illness and injury presenting to a Norwegian travel insurance company's helpline. Travel Med Infect Dis. 2007;5(3):165-170. doi:10.1016/j.tmaid.2006.09.006.

29. Sanftenberg L, Kramer M, Esser S, Schelling J. Insights into needs of business travelers to China from calls to a medical assistance provider. Heliyon. 2019;5(2):e01237. doi:10.1016/j. heliyon.2019.e01237.

30. Thompson DT, Ashley DV, Dockery-Brown CA, Binns A, Jolly $\mathrm{CM}$, Jolly PE. Incidence of health crises in tourists visiting Jamaica, west indies, 1998 to 2000. J Travel Med. 2003;10(2):7986. doi:10.2310/7060.2003.31628.

31. Shaw MT, Leggat PA. Illness and injury to travellers on a premium seniors' tour to Indochina. Travel Med Infect Dis. 2009;7(6):367-370. doi:10.1016/j.tmaid.2009.04.003.

32. Collins D, Tisdell C. Gender and differences in travel life cycles. J Travel Res. 2002;41(2):133-143. doi:10.1177/004728702237413.

33. Okazaki S, Hirose M. Does gender affect media choice in travel information search? on the use of mobile Internet. Tour Manag. 2009;30(6):794-804. doi:10.1016/j.tourman.2008.12.012.

34. Frändberg L, Vilhelmson B. More or less travel: personal mobility trends in the Swedish population focusing gender and cohort. J Transp Geogr. 2011;19(6):1235-1244. doi:10.1016/j. jtrangeo.2011.06.004. 